\title{
ANTIOXIDANT CHARACTERISTICS OF LATVIAN HERBAL TEA TYPES
}

\author{
Fredijs Dimiṇš, Velga Miḳelsone, and Miḳelis Kaṇeps \\ Department of Chemistry, Latvia University of Agriculture, Lielā iela 2, Jelgava, LV-3001, LATVIA; \\ fredisd@tvnet.Iv
}

Communicated by Dalija Segliṇa

The aim of the study was to characterise antioxidative properties and antiradical activity of the herbal tea collection in Latvia. High-pressure liquid chromatography and spectrophotometry methods were used to characterise antioxidant properties of herbal tea. Antiradical activity was determined spectrophotometrically. The antiradical scavenging activity was measured by the DPPH (2,2-diphenyl-1-picrylhydrazyl) reaction. The herbal tea antiradical scavenging activity was estimated as the broken down quantity of DPPH on 100 grams of the herbal tea. Individual polyphenols in the herbal tea were identified and determined by liquid chromatography. Antiradical scavenging activity of the herbal tea was found to be $104 \mathrm{~mol}_{100 \mathrm{~g}^{-1}}$ tea. The following polyphenols were identified chromatographically in herbal tea: gallic, caffeic, chlorogenic, ferulic acids, rutin, catechin, vanillin, and epicatechin. Altogether 12 different varieties of herbal tea samples were analyzed. The results showed that different types of herbal tea substantially differed in composition. Polyphenol content of herbal teas was in the range of $1 \mathrm{mg}$ in $100 \mathrm{~g}$ of tea up to $8 \mathrm{~g}$ per $100 \mathrm{~g}$ of tea. In the case of virus-related disease, infections and weakness of the organism, it is recommended to use tea with high content of rutin, as in Verbascum thapsiforme Schr., Alchemilla vulgaris $L$., Comarum palustre $L$. herbal tea.

Key words: herbal tea, polyphenols, antiradical scavenging activity.

\section{INTRODUCTION}

Herbal teas are widely used in traditional medicine. Antioxidant effect is one of the major descriptive characteristics of organic and medicinal activity.

In the body mitochondrial activity, during metabolism or as a result of environmental factors, such as pollution, radiation, smoking, pesticides, etc. exposure, leads to free radicals - atoms, molecules or ions with unpaired electrons superoxide, hydrogen peroxide, singlet acid, hydroxyl radical. These are highly reactive, unstable and can lead to oxidative stress - a chain reaction that causes cell and tissue damage, contributing to aging and increased risk of developing various diseases, such as cancer, heart disease, cataracts, etc. (Sailaja et al., 2011).

During oxidative stress, specific molecules actively react with proteins, lipids, and nucleic acid molecules, adding the missing electron, and thus creating other unstable molecules and inducing a chain reaction, such as via hydroxylated aromatic amino acids in protein molecules and oxidised-SH groups forming disulfide bridges - SS-bonds (Vīgants, 2008).

Unsaturated fatty acid-containing lipids with a large number of double bonds are readily oxidised. A variety of oxidation products, such as peroxides, hydroperoxide, alkanoles, aldehydes, carboxylic acids, etc., can inactivate the enzyme activity by binding to the active centres. Linoleic and arachidonic acid form malondialdehyde, as well as 4-hidroxynonenal, which is very toxic. Also cholesterol can be oxidised, resulting in total destruction of the cell membrane.

Nucleic acids participate in purine base guanine hydroxylation to form 8-hydroxy guanine (Vīgants, 2008).

Oxidative stress can reduce the body's antioxidant defense system and increase concentrations of oxygen and nitrogen in the active form (Vīgants, 2008).

Damage by free radicals can be reduced by antioxidant molecules that react with them, eliminating the unpaired electron, or making the active radical less active, terminating the chain reaction.

The endogenous system in the body is composed of several antioxidant enzymes - superoxiddismutase, catalase, glutationperoxidase, glutationreductase etc.

Well-known exogenous (with dietary imbibed) antioxidants are vitamins $\mathrm{C}$ and $\mathrm{E}$, lycopene, lutein, carotenoids, such as $\beta$-carotene, selenium, flavonoids, polyphenols, lignans, 
coenzyme Q10, and others. Most of them are vegetable products (Sailaja et al., 2011).

Polyphenols are chemical compounds with phenol rings. There is a big difference in the phenolic compounds regarding chemical structure, and they can be monomers or complex polymers.

Phenolic compounds of plants can be divided into two broad categories: 1) phenolic acids (oxometallic) and their derivatives, and 2) flavonoids (polyphenols). Phenolic acids and their derivatives, mainly esters, have more basic structures. Phenolic compounds constitute a wide group of representatives of caffeic acid, kumarin acid, vaniline, and gallic acid.

The flavonoid class of compounds has a more complex molecular structure, which is usually heterocyclic with attracted phenolic ring(s). Flavonoids include antocianidines (water-soluble pigment, which are oxidised flavonoles), catechins, isoflavones and proanthocyanidin (Robarts et al., 1999).

Polyphenols are the main antioxidant source from food. They are found in legumes, fruits and berries, and vegetables, red wine, chocolate, green tea, cereals and many herbal teas. Phenolic compounds constitute $50-70 \%$ of the weight of green tea, which is a key indicator of quality teas (Naghma and Hasan, 2007).

Plants consist of flavonoids, including catechins, proantocyanins, anthocyanins, flavones, flavonoles and their glycosides, which have antioxidant properties. The weight of these compounds can reach up to $30 \%$ of leaf dry matter (Naghma and Hasan, 2007).

The aim of the research was to describe the antioxidative characteristics of Latvian herbal teas by antiradical scavenging activity method and to determine the content of the main polyphenols.

\section{MATERIALS AND METHODS}

In this study, the antioxidative properties of Latvian herbal teas were estimated regarding polyphenol content and antiradical activity. Twelve varieties of herbal teas were analysed:

Origanum vulgaris L., Hypericum perforatum L., Chelidonium majus L., Achillea millefolium L., Calluna vulgaris L., Artemisia vulgaris L., Plantago major L., Comarum palustre L., Alchemilla vulgaris L., Calendula officinalis L., Verbascum thapsiforme Schr., Rubus idaeus L. (Rubine and Enina, 2004) (Table 1). All these plants are widely distributed in Latvia and are used every day in the form of herbal tea. They include a variety of polyphenols, which act as radical and nitrite neutralisers in the body, they may show antiviral effects (including HIV), and enzyme induction, such as in the cytochrome P-450 system and phase II conjugation systems. They are important in the human body, as they
HERBAL TEA VARIETIES ANALYSED IN THE STUDY

\begin{tabular}{|c|c|c|c|}
\hline No. & Tea sample & No. & Tea sample \\
\hline 1 & Plantain (Plantago major L.) & 7 & $\begin{array}{l}\text { Common origanum (Origanum } \\
\text { vulgaris L.) }\end{array}$ \\
\hline 2 & $\begin{array}{l}\text { Marsh cinquefoil (Comarum } \\
\text { palustre L. }\end{array}$ & 8 & $\begin{array}{l}\text { Common St. John's wort } \\
\text { (Hypericum perforatum L.) }\end{array}$ \\
\hline 3 & $\begin{array}{l}\text { Lady's mantle (Alchemilla } \\
\text { vulgaris L.) }\end{array}$ & 9 & $\begin{array}{l}\text { Greater celandine (Chelidonium } \\
\text { majus L.) }\end{array}$ \\
\hline 4 & $\begin{array}{l}\text { Calendula (Calendula officinalis } \\
\text { L.) }\end{array}$ & 10 & $\begin{array}{l}\text { Milfoil (Achillea millefolium } \\
\text { L.) }\end{array}$ \\
\hline 5 & $\begin{array}{l}\text { Wool mullein (Verbascum } \\
\text { thapsiforme Schr.) }\end{array}$ & 11 & $\begin{array}{l}\text { Wild wormwood (Artemisia } \\
\text { vulgaris L.) }\end{array}$ \\
\hline 6 & Red raspberry (Rubus idaeus L.) & 12 & Heather (Calluna vulgaris L.) \\
\hline
\end{tabular}

aid to avoid polyunsaturated fatty acid autoxidation (Higdon and Frei, 2012).

The scavenging activity of tea samples for the radical 2.2-diphenyl-1-picrylhydrazyl (DPPH) was measured as described (Meda et al., 2005) with some modifications.

$1 \mathrm{~g}$ of dry tea was extracted in $50 \mathrm{~mL}$ methanol. Extraction was carried out for 1 hour at $25^{\circ} \mathrm{C}$. The filtrate of the extract was used for further analysis. A volume $(1.5 \mathrm{ml})$ of each tea extract solution was mixed with $3 \mathrm{ml} \mathrm{DPPH}$ solution in methanol $\left(0.02 \mathrm{mg} \cdot \mathrm{ml}^{-1}\right)$, with methanol serving as the blank sample. The mixtures were left for $15 \mathrm{~min}$ at room temperature and then the absorbance was measured at 517 $\mathrm{nm}$.

As mentioned above, in the control analysis, methanol was used instead of tea extract. Based on the DPPH solution and sample solution concentration, light absorption was used to calculate the break down amount of DPPH ( $\mu$ mol per $100 \mathrm{~g}$ of tea), in relation to the control solution.

Chromatographic determination of individual polyphenols in tea samples was made by liquid chromatography. Eight polyphenols in teas were determined: rutin, gallic acid, epicatechin, catechin, ferulic acid, chlorogenic acid, vanillin and caffeic acid.

The analyses were carried out using a Shimadzu liquid chromatography LC-20AD, with a DAD (diode array detector: SPD M20A) using analytical C18 column chromatography. The eluting solvent was methanol (A, 20\%), water (B, $78.4 \%)$ and acetic acid $(1.6 \% \mathrm{C})$ in gradient mode: 17:50 minutes $-58.5 \% \mathrm{~B}$ concentration, $\mathrm{C}$ concentration of $1.2 \%$; 35 minute - end of analysis.

The sample injection into the chromatograph, using an automatic sample injection system SIL - 20AC. Fluent flow rate $1.0 \mathrm{ml} / \mathrm{min}$.

Determination of polyphenols was made by using multiple wavelengths: 253, 268, 278 and $298 \mathrm{~nm}$. $253 \mathrm{~nm}$ wavelength was used to determine rutin, and $263 \mathrm{~nm}$ - gallic acid, $278 \mathrm{~nm}$ - catechin, caffeic acid and vanillin, and 298 $\mathrm{nm}$ - chlorogenic acid, epicatechin and ferulic acid. 


\section{RESULTS}

A significantly higher concentration of rutin was observed in Hypericum perforatum. and Calluna vulgaris tea (Fig. 1).

The highest concentration of gallic acid occured in Rubus idaeus tea (Fig. 2). Rubus idaeus tea had a relatively higher concentration of catechin (Fig. 3).

Alchemilla vulgaris, Calluna vulgaris and Hypericum perforatum teas had higher concentrations of caffeic acid (Fig. 4).

Vanillin is known as a spice, and is used in a variety of foods. Vanillin is also found in tea. A relatively higher vanillin concentration was found in Alchemilla vulgaris, Calendula officinalis and Artemisia vulgaris tea (see Fig. $5)$.
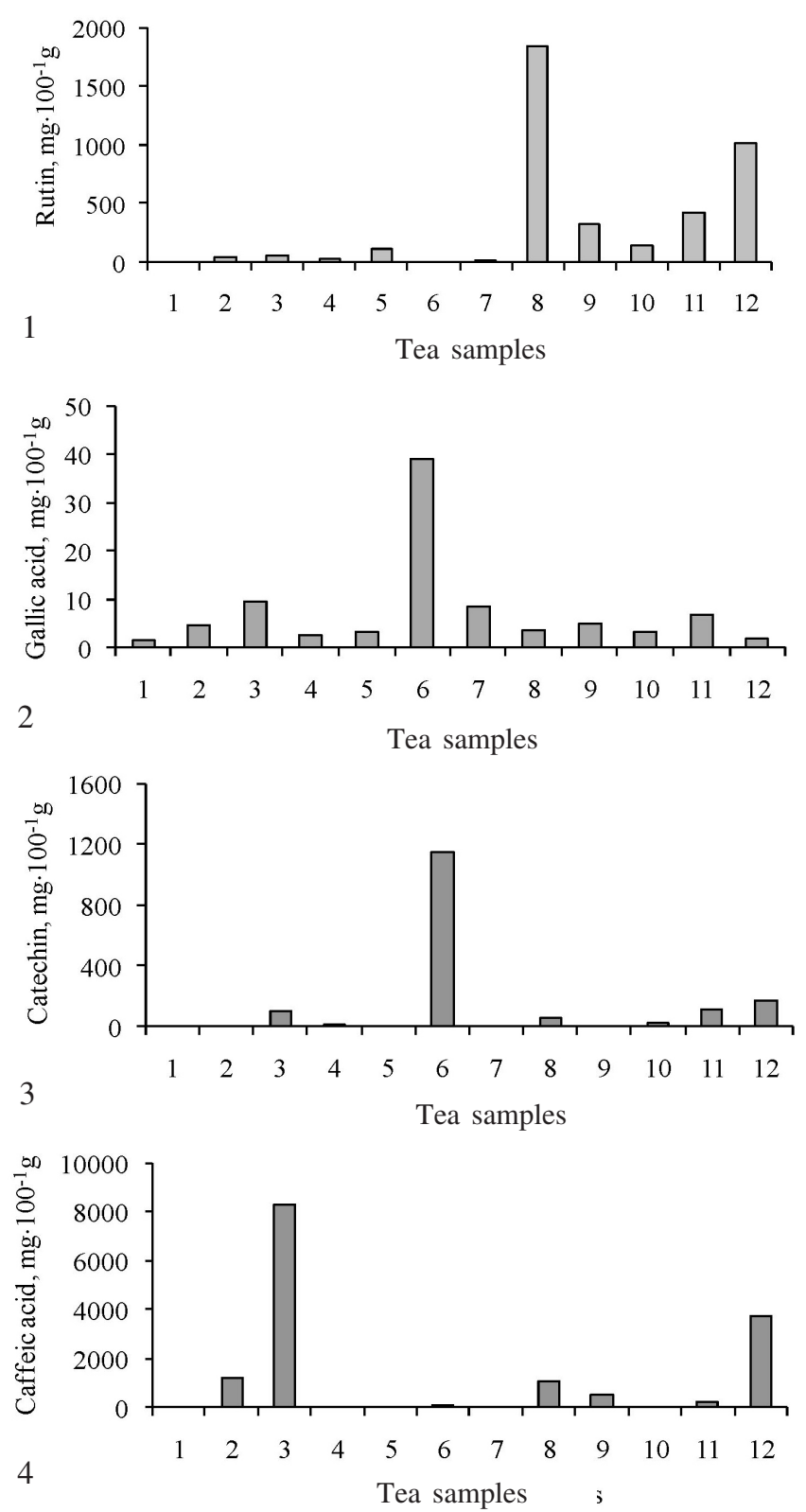

A relatively higher concentration of chlorogenic acid was found in Comarum palustre, and Achillea millefolium tea (Fig. 6). High chlorogenic acid concentration was also found in Alchemilla vulgaris and Hypericum perforatum teas.

The epicatechin concentration in teas was relatively low, and in the range from $0.07 \mathrm{mg} \cdot 100^{-1} \mathrm{~g}$ to $3.6 \mathrm{mg} \cdot 100^{-1} \mathrm{~g}$ of tea. Higher epicatechin concentration was found in Alchemilla vulgaris and Calendula officinalis teas (2.6 $\mathrm{mg} \cdot 100^{-1} \mathrm{~g}$ and $\left.3.6 \mathrm{mg} \cdot 100^{-1}\right) \mathrm{g}$.

Ferulic acid had relatively high concentrations in Origanum vulgaris tea (Fig. 7). Higher concentration of ferulic acid was also observed in Alchemilla vulgaris, Verbascum thapsiforme Schr. and Achillea millefolium tea.

In order to assess the total anti-oxidant tea value, they were assessed by total content of polyphenols in tea, as well as by
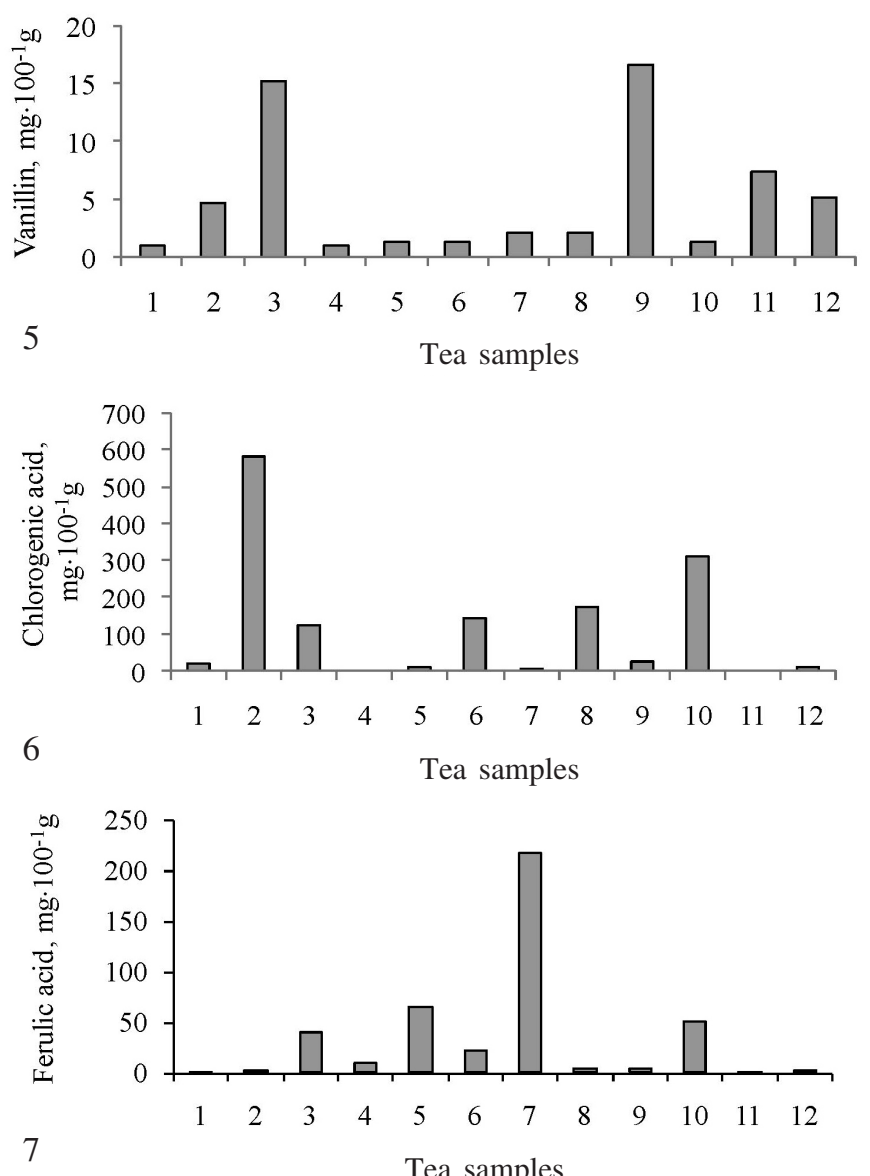

7

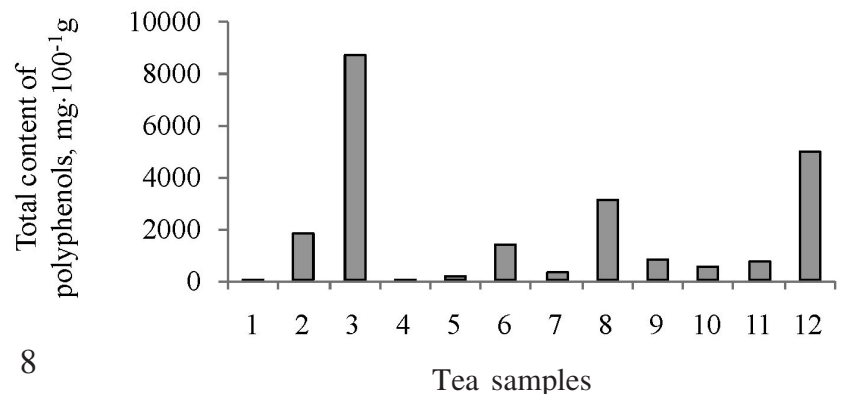

Fig. 1. Concentration of ployphenols in tea samples (numbers of tea samples identified in Table 1): 1) rutin; 2) gallic acid; 3) catechin; 4) caffeic acid; 5) vanillin, 6) chlorogenic acid; 7) ferulic acid; 8) total polyphnols. 
certain antiradical activity (Fig. 8). The highest polyphenol concentration was found in Alchemilla vulgaris and Calluna vulgaris tea, and somewhat lower in Comarum palustre, Rubus idaeus and Hypericum perforatum tea.

The antiradical scavenging activity in the analysed tea ranged from 6 to $104 \mu \mathrm{mol} \cdot 100^{-1} \mathrm{~g}$. The highest activity was in Calluna vulgaris tea (104 $\mu$ mol break down DPPH reagent per $100 \mathrm{~g}$ of tea). In other teas, the antiradical activity was in the range of 21 to $38 \mu \mathrm{mol} \cdot 100^{-1} \mathrm{~g}$.

\section{DISCUSSION}

It is known that rutin provides a more complete intake of vitamin $\mathrm{C}$ in the body. Therefore, it is used as a food supplement in combination with other substances. Rutin also has good anti-oxidant properties (Guardia et al., 2001).

Catechins have antibacterial properties and it is able to destroy viruses and bacteria. Similarly, it is a good natural antioxidant (Higdon, et al., 2003).

Caffeic acid has a spasmolytic and mitigating decreasing effect. Caffeic acid stimulates bile secretion. Chlorogenic acid has anti-bacterial, anti-inflammatory and antiviral properties. It also has antioxidant properties. Epicatechin is a powerful antioxidant. This is one of the rare flavonoids that in biologically active form is capable of reaching the brain (Mou-Tuan Huang et al., 1991).

Ferulic acid is widely used in cosmetics as an antioxidant and as a protective measure against the adverse effects of UV rays. Ferulic acid inhibits skin aging (Graf, 1992).

High antiradical activity assessed by total polyphenols content was found only in heather tea. However, teas have many other polyphenols, which were not analyzed. Also, anti-oxidant activity can be attributed not only to polyphenols, but also to specific vitamins, amino acids, etc.

To conclude, our results demonstrate that increased antioxidant concentrations were found in Alchemilla vulgaris, Calluna vulgaris, Comarum palustre, Rubus idaeus and Hypericum perforatum teas.
In cases of virus diseases, infections and weakness it is recommended to use tea to increase rutin, chlorogenic acid and catechin intake.

Tea with increased ferulic acid content can be used to prevent against skin aging and UV destructive exposure.

The estimated total antioxidant content is not the only parameter that should be used in tea evaluation, and other polyphenol and antioxidant concentrations should be considered.

\section{REFERENCES}

Frei, B., Higdon, V. (2003). Antioxidant activity of tea polyphenols in vivo: Evidence from animal studies. Proceedings of the Third International Scientific Symposium on Tea and Human Health: Role of Flavonoids in the Diet. http://jn.nutrition.org/content/133/10/3275S.full (accessed 27 July 2012).

Graf, E. (1992). Antioxidant potential of ferulic acid. Free Radical Biol. Med., 13 (4), 435-448.

Guardia, T., Rotelli, A. E., Juarez, A. O., Pelzer, L. E. (2001). Anti-inflammatory properties of plant flavonoids. Effects of rutin, quecetin and hesperidin on adjuvant arthritis in rat. II Farmaco, 56 (9), 683-687.

Higdon, J. V, Frei, B. (2003). Tea catechins and polyphenols: Health effects, metabolism, and antioxidant functions. Critical Rev. Food Sci. Nutr., 43 (1), 89-143.

Meda, A., Lamien, C. E., Romito, M., Millogo, J., Nacouluma, O. G. (2005). Determination of the total phenolic, flavonoid and proline contents in Burkina Fasan honey, as well as their radical scavenging activity. Food Chemistry, 91, 571-577.

Mou-Tuan Huang, Chi-Tang Ho, Chang Y. Lee. (1991) Phenolic Compounds in Food and Their Effects on Health. II. Antioxdants and Cancer Prevention. Washington, DC: American Chemical Society. 402 pp.

Naghma, K., Hasan, M. (2007). Tea polyphenols for health promotion. Life Sci., 81 (7), 519-533.

Rubine, H., Eniņa, V. (2004). Ārstniecības augi [Herbal plants]. Rīga: Zvaigzne. 344 lpp. (in Latvian).

Robarts, K., Prenzler, D. P., Tucker, G., Swatsitang, P., Glover, W. (1999). Phenolic compounds and their role in oxidative processes in fruits. Food Chem., 66 (4), 401-436.

Rao, P. S., Sireesha, K., Aparna., Y, Sadanandam, M. (2011). Free radicals and tissue damage: Role of antioxidants. Free Radicals Antioxid., 1 (4), $2-7$.

Vīgants, A. (2008). Cilvēka biok̦īmija un molekulārā ķīmija [Human Biochemistry and Molecular Chemistry]. Rīga: LU Akadēmiskais apgāds. 123 1pp. (in Latvian).

Received 16 March 2013

\section{LATVIJĀ VĀKTO ZĀLU TĒJU ANTIOKSIDATĪVO ĪPAŠİBU RAKSTUROJUMS}

Darbā ir pētītas dažādu Latvijā vāktu zāḷu tēju antioksidatīvās īpašības, izmantojot augstspiediena šķidruma hromatogrāfijas un spektrofotometrijas metodes. Tika analizētas 12 tējas: parastā raudene (Origanum vulgaris L.), divškautnuu asinszāle (Hypericum perforatum L.), lielā strutene (Chelidonium majus L.), parastais pelašķis (Achillea millefolium L.), sila virsis (Calluna vulgaris L.), parastā vībotne (Artemisia vulgaris L.), lielā cel̦teka (Plantago major L.), purva vārnkāja (Comarum palustre L.), parastais rasaskrēsliņ̌š (Alchemilla vulgaris L.), ārstniecības klingéerīte (Calendula officinalis L.), deviṇvīru spēks (Verbascum thapsiforme Schr.), meža avene (Rubus idaeus L.). Tēju antiradikālā aktivitāte tika noteikta spektrofotometriski, izmantojot DPPH (2,2-difenil-1-pikrilhidrazils) reaǵentu. Iegūtie antiradikālās aktivitātes rezultāti izteikti uz noārdītā DPPH reaǵenta daudzumu 100 g tējas. Atseviški fenolu savienojumi — galluskābe, kafijskābe, hlorogēnskābe, ferulskābe, rutīns, katehīns, vanilīns un epikatehīns — identificēti, izmantojot škidruma hromatogrāfiju. No iegūtajiem rezultātiem var secināt, ka palielināts antioksidantu saturs ir rasaskrēsliṇu, viršu ziedu, asinszāḷ, aveņu tējām. Dažādu infekciju, vīrusu saslimšanu un organisma vājuma gadījumā ieteicams lietot tējas, kas satur rutīnu, hlorogēnskābi un katehīnus. Tējas ar palielinātu ferulskābes saturu ieteicams lietot kosmētikā kā līdzekli pret ādas novecošanos un UV staru kaitīgo iedarbību. 